https://doi.org/10.18485/kij.2021.68.2.14

ЛИДИЈА 3. САВЙ ${ }^{*}$, докторанд

Универзитет у Београду

Филолошки факултет
Оригинални научни рад

Примљен: 10.10.2021.

Прихваћен: 22.11.2021.

\title{
МЕТОДИЧКИ ПРИСТУП БЕСЕДНИШТВУ И КУЛТУРИ ГОВОРА: О ЗНАЧАЈУ ДОБРО ИЗГОВОРЕНЕ РЕЧИ
}

\begin{abstract}
Савремени начин живота утицао је лоше на усмено изражавање, али је парадоксално изазвао и препород идеје о значају излагачке писмености и културе јавног говора уопште. Иако се чини да је свест о значају квалитетног усменог изражавања новијег датума, важно је напоменути да је она присутна још од античких времена. Начин на који говоримо одувек је био одраз образовања и васпитања, и један је од основних алата за презентовање и самопрезентовање. Циљ рада није да форму (начин на који нешто говоримо) ставимо испред садржаја изговореног, већ да укажемо на њихову међузависност, јер добар садржај без добре форме губи на свом значају, а форма без садржаја не постоји. Осим што упућује на проблеме, рад нуди конкретна решења, применљива у свакодневној наставној пракси.
\end{abstract}

Кључне речи: култура говора, излагачка писменост, беседништво, дикција, артикулација.

Двадесет и први век донео је са собом ренесансу излагачке писмености. Иако се многима чини да се свест о значају и предностима доброг јавног наступа одједном појавила, морамо истаћи да је она готово одувек постојала. Предлажемо да пажњу усмеримо ка дубљој прошлости, јер нам то може помоћи да уочимо да је начин на који се нешто говори одувек био важан готово колико и садржај изговореног, што нас доводи до закључка да је свест о значају естетике јавног говора одувек постојала. О томе најбоље сведочи чињеница да је у Атини и другим полисима у вековима пре нове ере вештина говорења била важна у свим сегментима живота (један од најважнијих циљева образовања било је овладавање реториком), а једна од најпознатијих прича јесте древна прича о Демостеновим наступима праћеним подсмехом. Поменути антички говорник је

"saviclidija9@gmail.com 
захваљујући сугестији свог пријатеља схватио да је за један говор у јавности, поред припремљеног садржаја, веома важно и то како се тај садржај изговара, дакле - начин.

Желимо да истакнемо да циљ овог рада није давање предности начину у односу на садржај изговореног. Напротив. Сматрамо да је предмет говора, односно садржај, најважнији елемент јавног наступа, међутим, да би један јавни наступ био комплетан и да би код публике изазвао жељену реакцију, веома је битно да се мисао изговори на добро припремљен, динамичан и упечатљив начин. Јер, колико год да је тема актуелна, а суштина важна и занимљива, уколико публици идеју саопштимо на монотон, несликовит и досадан начин, наше време проведено на сцени узалуд је потрошено. Публика ће врло брзо изгубити интересовање, а проценат запамћеног биће неупоредиво мањи у односу на слушање говорника који током свог наступа користи различите елементе осликавања $u$ динамизовања.

Имајући у виду да су наставници и професори пребукирани наставним програмом, а да су часови предвиђени за говорну културу (за детаљно бављење њом) услед недостатка времена углавном сведени на минимум (у пракси се врло често потпуно изостављају), желимо да укажемо на то да је рад на елементима јасно артикулисаног, гласног, ритмичног, добро уобличеног, одмереног, интересантног и аргументованог изражавања - неопходан. Управо ћемо због тога покушати да понудимо могуће облике рада којима бисмо могли да позитивно утичемо на естетику изражавања ученика, како током редовне наставе тако и на додатним часовима у виду секције.

И сами смо сведоци чињенице да је све већа пажња пословних људи који раде на самоедукацији усмерена управо ка вештинама јавног наступа и презентовања, о чему говори и отварање све већег броја приватних школа и института за усавршавање излагачких способности. Управо ову чињеницу можемо посматрати као аларм који упозорава колико је ова тема до сада у нашем образовно-васпитном систему била запостављена, а уједно представља и прави показатељ све веће потребе за запосленима (данас су то ученици, а сутра угледни представници својих професија) који добро владају излагачком писменошћу. Стога, рад са ученицима на унапређивању способности квалитетног самопрезентовања, презентовања и завидног усменог и писменог изражавања истичемо као један од најважнијих задатака наставе српског језика и књижевности.

Још у античко доба лепо исказана мисао сматрана је саставним делом васпитања и образовања. Начин на који се говори био је од пресудне важности за обликовање мишљења о некој особи, о чему сведочи и чувена Сократова мисао: „Проговори да видим ко си”, настала пре нове ере, али мисао која ни данас не губи своју актуелност. Сложићемо се, ни у савременом добу образованог и успешног човека не можемо замислити без вештине лепог обликовања својих мисли и идеја. „Као што је неучтиво у једно отмено друштво ући неумивен и неочешљан, тако је исто неучтиво и недостојно образована човека да своју мисао пусти у друштво неумивену и неочешљану. [...] Најнеплеменитија осећања, као 
што су, на пример, туга, радост, весеље, образован ће човек другачије изразити од необразованог." (Нушић 1938: 15)

Крис Андерсон у својој књизи ТЕД говори истиче значај доброг говорења у XXI веку. Говорећи о томе, Андерсон сеже далеко у прошлост проналазећи паралелу са садашњим тренутком. Наводи свима добро познату слику усменог приповедања: логорска ватра, старац који устаје осветљен треперавом светлошћу и почиње да прича док су све очи упрте у њега. Андерсон у старцу види вођу, представника заједнице који има моћ да пробуди саосећање, подстиче узбуђење и дели другима знање, а уз то наводи да је жива реч данас стекла нове моћи (Андерсон, 2016: 11-12):

„Наш круг око логорске ватре сада је цео свет. Захваљујући интернету, говор у малој сали на крају може видети и на милионе људи. Баш као што је штампа у великој мери увећала моћ писаца, тако је интернет у огромној мери увећао утицај говорника. [...]Ова револуција покренула је ренесансу у јавном говорништву. Многи од нас су претрпели године дугих и досадних предавања на факултету, бескрајне проповеди у цркви или предвидиве кампањске говоре политичара, на које човек може само да заколута очима. То не мора бити тако. Ако се одржи како треба, говор може наелектрисати просторију и променити публику широм света. Ако се одржи како треба, говор је много моћнији од сваке речи у писаном облику.[...]У двадесет и првом веку требало би да се излагачка писменост учи у свакој школи. Заправо, пре времена књига, она је сматрана суштинским делом образовања, мада са старијим називом: реторика. Данас, у време повезаности целог света, треба обновити ту племениту вештину и учинити је четвртим стубом образовања (читање, писање, математика и реторика)."

Потребно је нагласити да су само делимично у праву они који под појмом дикиија подразумевају артикулацију. Дикиија је појам који обухвата, како Нушић сматра, многе елементе говора, узимајући у обзир: а) реченични склоп, б) јасност изражавања, в) боју речи, г) граматичко наглашавање, д) логично наглашавање, ђ) патетично наглашавање и е) усмену интерпункцију (Нушић 1938 : 117-120). Он сматра да је дикција заправо леп и правилан изражај речи и реченица који омогућава што складније саопштавање мисли (правилност и лепота неке реченице зависе од њеног склопа, у чему значајну улогу има синтакса).

Наравно, један од основних услова дикције, по Нушићевом мишљењу, јесте и јасност изражавања, која се не односи на стилску већ на техничку страну. Веома је важно да слушаоци чују говорника и да разумеју сваку његову реч (битно је да ниједан глас који говорник изговара не буде „прогутан” или нејасан). Сложићемо се да је данас, у времену онлајн комуникације, квалитет артикулације (посебно код младих) на веома ниском нивоу. И чини се да је из дана у дан на све нижем. Усмереност на куцање порука уместо на усмену размену информација, коришћење скраћеница, углавном страног порекла, чак и тенденција ка скраћивању тих скраћеница - све су то појаве које утичу лоше на културу говора. Главни разлози коришћења скраћеница јесу, са једне стране, императив брзине размене порука, а са друге лењост да се напише/изговори реч у целини. Исте елементе можемо навести и као узроке незавидног вербалног изражавања, а пре свега - лоше артикулације. Одсуство жеље да се уложи напор како би се 
одређена реч, а потом и реченица (самим тим и изјава/говор) правилно гласовно обликовали, резултира неразговетношћу. Зато ћемо посебну пажњу обратити управо на лепоту ваљаног обликовања гласова.

Када је реч о боји, Бранислав Нушић наводи да је веома важно на који начин изговарамо неку реч (Нушић 1938: 118): „Не може се истим тоном обојити реч мајка и реч разбојник. Реч мајка захтева извесну топлину у изражају, а та би топлина била у противности са појмом разбојник.” Наравно, треба имати у виду да бојење речи никако не сме бити вештачко, напротив, мора звучати спонтано, а посебно је потребно разликовати га од патетичног наглашавања. И у једном и у другом случају ради се о издвајању једне речи у односу на друге, али је разлика у томе што се бојење примењује код сваке речи, чак и код оних које се не наглашавају и не носе реченицу. Поред тога, бојеље представља карактерисање појма, док патетично наглашавање истиче баш ту осећајност.

Правилна акцентуација (или како је Нушић назива - граматичко нагламавање) такође је један од главних елемената добре дикције. Уколико је акцентуација лоша, осим што може произвести комичан ефекат, кадра је да измени и смисао реченице (један од најпознатијих примера јесте именица - град, која, у зависности од тога на који начин се акцентује, може означавати у једној варијанти насељену област, а у другој - временску непогоду). С обзиром на то да је за ваљано акцентовање важан континуирани рад и вежбање слуха, препоручујемо наставницима и професорима да у редовној настави повремено ученицима понуде вежбу која би освежила знање везано за акцентологију. На тај начин би се континуираним радом, обнављањем и систематизацијом градива побољшала језичка пракса ученика - пасивно владање правилима постало би функционално знање.

Као још један од елемената добре дикције издвајамо - логички акценат. Логички акценат подразумева наглашавање одређене речи у реченици како би се посебно истакло значење те мисаоне целине. Колико је граматички акценат важан за значење речи, толико је логички битан за семантику реченице. Нушић у својој Реторици даје један користан савет за вежбање логичког акцента (Нушић 1938: 119): „Овоме правилу дикције беседник мора да поклони нарочиту пажњу. Правилно логично наглашавање може се постићи најпре гласним читањем стилски добрих књижевних дела, уз старање да се наглашавањем да свакој реченици њен пун смисао.” Као што видимо, корелацијом са наставом књижевности можемо мотивисати ученике да читајући литературу истовремено раде и на елементима вербалне писмености. Чини се, ипак, да је поменути предлог добар тек за каснију фазу рада са ученицима. За почетак, док ученици још усвајају знања о логичком акценту, предлажемо једноставније задатке. Један од њих наводимо у наставку. Ђацима се може понудити нека једноставна реченица коју треба да изговоре на неколико начина, дајући јој, у зависности од тога које речи наглашавају, другачије значење. На пример: а) Миш уз пушку, миш низ пушку; б) Миш уз пушку, миш низ пушку; в) Миш уз пушку, миш низ пушку. Као што можемо да приметимо, у првој реченици логичким акцентом наглашена је реч миш, чиме 
је у фокус доведена информација у вези са тим ко/шта иде уз и низ пушку. У другој је истакнуто како се миш креће, док је у трећој акцентовано то по чемусе миш креће. Циљ ове вежбе јесте да се ученицима приближи значај логичког акцента, односно да уоче колико је распоред логичког акцента важан за смисао одређеног исказа. С обзиром на то да ученицима за ову вежбу није потребна никаква претходна припрема, она се може практиковати на редовним часовима у комбинацији са другим градивом и тако смањити потенцијална монотонија, а уједно знатно утицати на квалитет усменог изражавања ученика.

Колико су за писану реч важни знакови интерпункције, толико је за говор значајна вербална интерпункиија и њено изговарање. Без ње не бисмо имали свест о крају једне мисли и почетку друге, не бисмо знали о каквој изјави/реченици је заправо реч (обавештајној, упитној или узвичној, зависној или независној). Из наведеног примећујемо да је суштина ове две врсте интерпункције иста (и једна и друга дају изјави пун смисао), али је важно нагласити да су средства њиховог испољавања битно другачија (тачка и запета у говору се бележе дужим и краћим паузама, а знак питања или узвика, на пример, изговарају се посебном интонацијом која реченици даје упитни, односно узвични карактер). Видимо, дакле, да је интонација од изузетног значаја за обликовање целовите информације, те да је никако не смемо запоставити, као ни друге елементе вербалног изражавања.

Нушић разликује паузу за став (њен задатак је да означи завршетак једне целине, једног дела беседе) и паузу за ефекат (или психолошку паузу, јер се употребљава на крају некакве снажне реченице која треба да остави што бољи утисак на слушаоце). Ми додајемо да је пауза веома важна и када желимо да нагласимо нешто унутар саме реченице. У неком тренутку је пожељно да, без обзира на то што на неком месту нема никаквог знака интерпункције, паузом најавимо реч коју публика треба да упамти. На пример, уколико желимо да истакнемо да је на часовима српског језика и књижевности веома важно радити на квалитету изговорене речи, то можемо учинити на следећи начин: На часовима српског језика и кьижевности веома је важно радити на (пауза) квалитету изговорене речи. Ми смо, дакле, паузом подигли ниво пажње слушалаца, заинтригирали смо их за оно што је битно, а потом им то што је битно и саопштили. На тај начин поенту, коју желимо да публика упамти, издвајамо од остатка реченице, чиме непогрешиво утичемо на памћење важне информације. Осим овог, постоји још један начин на који можемо одређену реч нагласити тако да је издвојимо од осталих. Реч је о техници која се заснива на разлагању важне речи на слогове: На часовима српског језика и књижевности веома је важно радити на ква-лите-ту изговорене речи. И ова техника је јако делотворна, а добри говорници је свесно врло често користе (Роксандић 2020: 65).

Изузетно је важно напоменути да је монотонија највећи непријатељ сваког јавног наступа. Зато је много важно имати у виду ритам као један од најважнијих елемената сваког доброг говора (Роксандић 2020: 63): „Ритам у говору представља непрекидно смењивање различитих говорних елемената. Кључна 
реч је смена. Смењивање брзог и спорог ритма, гласног и тихог говора, пауза и осталих говорних елемената, одлике су занимљивог, живог говора који држи пажњу. Уколико говоримо ритмично, људи ће нас радо слушати, неће им бити досадно.” Имајући ово на уму, сваки говорник/ученик приликом рада на свом говору треба да одреди делове које је потребно изговорити гласније, тише, да обележи информације преко којих је потребно прећи брже (реч је углавном о зависним реченицама, апозицијама, сегментима које понављамо или које успут помињемо), као и делове на којима треба мало дуже да се задржи због њиховог значаја (кључни појмови, поруке, итд.). Управо ова смена различитих елемената у један јавни наступ уноси потребну динамику, а публику чини заинтересованом и концентрисаном.

Како Слободан Роксандић у својој књизи наводи, људски мозак током једног минута може да обради укупно око осам стотина речи, од чега чује само сто четрдесет. Зато је изузетно важно да их говорник другачије наглашава, јер само на тај начин може да задржи пажњу публике: „Нешто што прво приметимо када неко проговори јесте - артикулација. Она подразумева јасан изговор свих гласова. [...] Колико пута сте само другима тражили да понове нешто јер их нисте разумели? Некада бисмо желели да испред наших саговорника постоји превод, као кад гледамо филм на страном језику па укључимо титл” (Роксандић 2020: 40). Као што смо најавили у једном од претходних пасуса, желимо да скренемо пажњу на значај процеса унапређивања артикулације ученика основних и средњих школа. О чему год да говоримо, било приватно било да излажемо пред већим бројем људи, неопходно је да информација коју пласирамо дође до оних којима је упућена. Зато је веома важно да у потпуности владамо својим говорним апаратом.

С обзиром на то да у уџбеницима за основне и средње школе углавном можемо да приметимо одсуство вежби за артикулацију, или њихово присуство на веома оскудном нивоу, треба напоменути да ћемо овом предмету прићи пре свега из практичног угла, са жељом да понудимо што свеобухватнију палету вежби за усавршавање говора. Марина Марковић у својој књизи Глас глумциа наводи истраживање Љиљане Грујић Еренрајх, која говори о значају вежби за еластичност и оживљавање мишића меког непца, гркљана, језика, усана, носа, односно органа који учествују у обликовању гласа, примећујући да артикулација веома битно утиче на гласовну продукцију, односно да од обликованог гласа зависи чујност говорника (Марковић 2002: 41).

Добро је познато колико је пре неке физичке активности важно загревање тела. Тако је и са говором. Како би квалитет говорне радње био што бољи, пре него што је започнемо, неопходно је загрејати мишиће лица и усне дупље (језик, усне, доњу вилицу). Марина Марковић у својој књизи Глас глумца наводи неколико веома корисних вежби за загревање фацијалних мишића (Марковић 2002: 134): а) скупити уста, па их покретати с лева на десно и у обрнутом смеру, затим кружно, уз изразите покрете лица, снажно до јагодичних костију; б) намрштити ce, наборати лице; в) раширити очи, подићи чело и обрве, готово као код кинеске 
маске; г) поновити претходну вежбу, али широм отворених уста (отворити уста вежбајући горњу и доњу вилицу).

Ученици, посебно они млађег узраста, врло позитивно реагују на вежбе које подразумевају наглашену експресију лица (пренаглашено представљање емоција, на пример). Задавши одређену емоцију или стање, професор/наставник треба да мотивише ученике да мимиком представе ту емоцију/стање, ангажујући што већи број мишића лица (наставник/професор треба да инсистира на што јачој експресији). Осим поменуте, у наставку наводимо и вежбе које су такође врло корисне и интересантне, а у пракси потврђене као изузетно делотворне: жвакање замишљене жваке (ученик симулира жвакање жваке која временом постаје све већа и тврђа), опонашање краве која прежива (лагано кружно кретање доње вилице уз повремено додиривање усана), као и вежба која подразумева гурање унутрашњости образа језиком. Поменути примери код ученика често изазивају смех, што може, уколико наставник/професор уме да контролише новонасталу ситуацију, веома позитивно да утиче на квалитет часа, чинећи атмосферу пријатнијом, а ученике добро расположеним.

За правилно обликовање гласова у усној дупљи веома је важан рад на покретљивости корена, врха и средишњег дела језика. Стога, Марина Марковић (Марковић 2002: 135) истиче да је неопходно изражајно изговарање гласовних вежби (при чему треба имати у виду да је претераност пожељна - важно је инсистирати на што јачем отварању уста): а) лоа-лое-лои-лоу; б) те -ле - ке-фе - ве - се-же; в) ла-ла-ла-ле-ле-ле-ли-ли-ли-ло-ло-ло-лу-лу-лу.

Лења артикулација је веома честа појава, нарочито међу младима. Њен најчешћи узрок јесте готово потпуно одсуство кретања горње усне, а како је познато, за добру артикулацију је важно да усне не буду непокретне, већ активне и флексибилне. Управо због тога у наставку наводимо вежбе које се могу користити како бисмо унапредили активност и продуктивност својих артикулатора: усана, вилице и језика (Марковић 2002: 135): а) раширити усне и изговарати

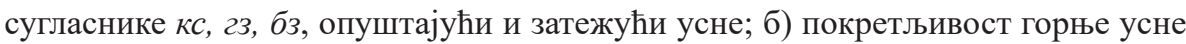
може се постићи изговарањем спојених сугласника $24,6 н, m н, \partial н$ (горња усна је приликом извођења ове вежбе готово залепљена за горње зубе и десни горње

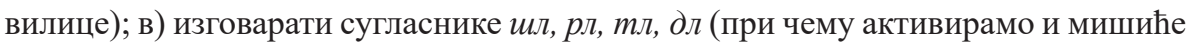
доње усне и доње вилице).

Квалитету артикулације у великој мери доприносе задаци који подразумевају комбиновање самогласничко-сугласничких група. Они се често раде заједно са вежбама за динамику гласа (изговарање вежби од најспоријег до најбржег нивоа - у климаксу, и обрнуто, од најбржег до најспоријег - у антиклимаксу), као и са вежбама за јачину гласа (изговарање од најтишег до најгласнијег нивоа и обрнуто, имајући поново у виду климакс и антиклимакс): а) тдлна - тдлне тдлни - тдлно - тдлну; б) бабаба - дадада - гагага - бадага - бадага - бадага; в) $p c-\pi c-m c-c a-p c-\pi c-m c-c e-p c-\pi c-m c-c u-p c-\pi c-m c-c o-p c-\pi c$

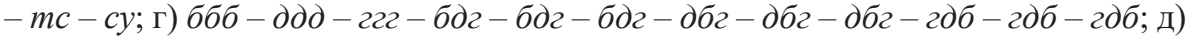


jojojojoja - jojojojoje - jojojojoju - jojojojojo - jojojojojy; ђ) баобабаба - баобабабе - баобабаби - баобабабо - баобабабу; е) вивовивова - вивовивове - вивовивови - вивовивово - вивовивову; ж) бпвфмнмнмна - бпвфмнмнмне - бпвфмнмнмни - блвфмнмнмно - блвфмнмнмну; з) изговарање азбуке у низу у једном даху (у почетку два, потом три-четири или више пута) - најважније је да сви гласови буду правилно изговорени без обзира на брзину извођења; и) изговарати азбуку стакато, при трчању у месту, застати приликом изговарања вокала, као у заустављеном залеђеном покрету, одржати дужину вокала у певаном облику, затим наставити са изговарањем азбуке (уколико је потребно, удахнути поново); j) не изговарајући $м$, брујећи затворених уста, масирати језиком десни, потом удахнути поново и отворити благо уста изговарајући неколико пута заредом вокале у правилном временском интервалу: ам, ем, им, ом, ум (Марковић 2002: 137).

Наведене вежбе су углавном ученицима потпуно непознате, те почињу да их раде са нескривеним чуђењем, међутим, то чуђење врло брзо прерасте у опште одушевљење и забаву. Наравно, поред великог броја наведених вежби, никако не смемо изоставити брзалице, које су ученицима далеко познатије. Осим што су део народне традиције, оне представљају неизоставну карику током загревања и унапређивања квалитета говорног апарата. Њих, попут већ наведених вежби, такође можемо извести са градацијом у гласност, варирањем темпа или висине тона (климакс и антиклимакс).

У наставку наводимо брзалице које су, како је пракса показала, веома занимљиве ученицима основних и средњих школа (Марковић 2002: 162): а) Миш уз пушку, миш низ пушку; б) Лежи куја жута украј жута пута; в) Луду булу у ту густу иуму вуку; г) Клупчићем ћу те, калемчићем ћеш ме; д) Стала мала Мара накрај стара хана сама; ђ) Невеселе снене жене плеле тешке мреже; е) Четири чавчића на чунчићу чучећи ичиучу; ж) Около дођох вођо потоком топовском рову; з) Лепа Лепосава за Лазом лудује, а он ликује; и) Краљица Клара и краљ Карло крали кларинет; ј) Мирили Мирини мирисни и дивни шимшири; к) Црн јарац, ирн трн, ирн брсти трн. Отуд иде ирн трн да одгризе ирном трну црн врх. Црн трнче, не одгризи црном трну црн врх...

Треба напоменути да све наведене вежбе можемо изговарати са или без физичке препреке у устима. Препорука је свакако да, уколико је то могуће, практикујемо што чешће извођење задатака уз одређену препреку (за свакодневно вежбање могу послужити оловка или пампур). Након изговарања текста на тај начин, можемо приметити како је цео говорни апарат разгибан (болуцкање усана/образа знак је да су вежбе за артикулацију правилно урађене) и запазити да речи слободно и лако теку, без напрезања мускулатуре лица, не наилазећи на препреку, без артикулационих грешака, што и јесте главни циљ извођења поменутих вежби.

Када би неко у низ предмета који могу да буду у корелацији са културом говора сврстао и физичку културу, верујемо да би се многи запитали о каквим је додирним тачкама реч. Поменута корелација односи се на вежбе за ослобађање гласа, вежбе за правилан тип дисања, за респирацију и загревање у седећем, као 
и вежбе дисања у стајаћем положају, а могуће их је применити само уколико то околности дозвољавају. С обзиром на то да је у учионицама простор (у односу на број ученика) често веома скучен, ове вежбе наводимо као бонус програм за све оне који су у могућности да га спроводе на редовним часовима, као и за оне који културом говора желе да се позабаве темељније у оквиру секције.

Када је реч о вежбама за ослобађање гласа, треба напоменути да су оне веома корисне за гласовну продукцију и отклањање напетости у пределу гркљана (Марковић 2002: 125). Савет је да се током загревања тела (које је саставни део припреме за сваки јавни насуп) једноставно пусти глас (спонтан и слободан, нипошто грлен). У наставку наводимо предлоге начина кретања које можемо искористити у овој вежби (напомињемо да покрет треба да тече синхроно са ослобађањем гласа): трчање у месту, трчање у месту уз подизање колена, трчање у месту уз забацивање ногу, поскакивање, скакутање, марширање, елегантан ход, успорен покрет... Важно је истаћи да тип кретања никако не сме да утиче на продукцију гласа - глас се не сме изгубити без обзира на то о ком начину кретања је реч.

Вежбе за дубоки дах (костоабдоминално дисање) доприносе квалитету изговарања дужих мисаоних целина „у једном даху”. При изговарању дужих исказа некада је веома важно не прекидати мисао паузама за удах. Зато је неопходно савладавање костоабдоминалног дисања, које нам омогућава да на природан начин изговоримо захтевније, обимније реплике, не прекидајући природан ток мисли. У наставку наводимо неколико вежби које су у том смислу веома корисне: а) удисати дуго, бројећи у себи, прво до пет, потом до осам и на крају до десет. Тако се активирају мишићи удисачи и навикавају се на поступан рад, без прескакања било ког важног дела процеса. Издахнути без озвучавања. Издисај може бити на $a x$ или $x a$; б) удахнути као у претходној вежби, али сада нагло издахнути и потрошити читаву количину ваздуха (овој вежби је изражен рад дијафрагме); в) удахнути, бројећи до пет, задржати ваздух до три, издахнути прво на $a x$ потом на $a j$ и $c$; г) сести на под, удисати уз подизање руку изнад главе, спуштајући се уназад до пода пратећи покрет руку. Издисај нека тече уз подизање руку и лагано прегибање (савијање кичме) тела ка напред, до колена; д) удисај уз бројање до пет, задржати дах три секунде, а потом издисати на $c$ уз лагано кружење главом с лева на десно. Поновити исто са покретом главе у другом смеру; ђ) удисај уз подизање руку изнад главе и издизање на прсте, издисај на $c$ уз лагано успорено спуштање на пете и опуштање руку поред тела; е) и за крај, веома је важна и опште позната вежба - три нивоа даха. Ову вежбу чини поступни и парцијални удисај, при чему се праве паузе у три етапе, што активира три групе мишића. Удисај почиње од дијафрагме, абдоминалних и трбушних мишића. Када се овај појас испуни ваздухом, настаје кратка пауза током које се дах држи ослоњен на дијафрагму, без покрета. Потом се шири средишњи део трупа, уз активирање косталних и интеркосталних мишића, након чега се поново прави пауза. У трећој етапи испуњавају се груди, леђни појас, размичу лопатице и дах долази готово до потиљачног дела главе. Након још једне кратке 
паузе почиње издисај, при чему се поново поштују етапе и паузе (издише се у три нивоа, од главе до трбушних мишића). Ова вежба је од изузетног значаја за све који се баве јавним говором, јер утиче на повећање капацитета плућа (Марковић 2002: 127-130).

Као што можемо да приметимо, палета вежби за контролу дисања и загревање гласа изузетно је велика. Она се чак може проширити и варијацијама, уколико су наставници/професори за то расположени. Важно је само нагласити да оне не одузимају много времена и да их је могуће практиковати и на редовној настави у оквиру уводног или завршног дела часа, независно од теме која је тог дана предмет обраде. Верујемо да би умерен, али редован приступ гласовним вежбама временом резултирао бољом артикулацијом ученика, што и јесте један од циљева бављења културом говора.

Технолошки помаци, промене у комуникацији, све чешћа изложеност великом броју људи (на састанцима, конгресима, семинарима, презентацијама), као и нове професије на различитим друштвеним мрежама, утицали су на то да смо постали све више окружени онима који желе да нам нешто саопште. Живимо, дакле, у времену креирања и пласирања порука које нам се упућују са свих страна, али у мору свих њих примећујемо да је квалитет изговорених информација на незавидном нивоу.

Не само да је реч о граматичким грешкама попут кафа за понети (знамо да предлог никада не иде уз глагол), већ се све чешће сусрећемо са непотпуним речима, речима којима неки гласови услед лоше артикулације једноставно недостају. С обзиром на то да су у медијима (медијима у најширем смислу - имамо у виду и друштвене мреже) све више присутне личности са лошом културом говора, ученици (који су циљна група баш тих познатих личности) готово да немају квалитетне узоре у оквирима својих интересовања. Њихови идоли (јутјубери углавном) на лошим говорним навикама (које подразумевају поштапалице, псовке, лошу артикулацију) граде свој публицитет. То изузетно негативно утиче на младу особу која је тек кренула путем образовања и васпитања.

Типичан пример јутјубера који је стекао велику популарност међу младима јесте особа која уместо да изговори шалим се, изговара шаим се, дакле, изоставља глас л. Та мана коју је он претворио у фазон толико је заживела међу његовом публиком, да су ретки они који је нису усвојили. Не желимо овом приликом да бацимо сенку само на ову нову професију. Нажалост, све више примећујемо лошу дикцију и лоше говорне навике и код оних коју су школовани за то да буду добри говорници. Имамо у виду поједине младе глумце који су добили прилику да се одмах на почетку своје каријере прославе и стекну велику популарност међу млађом публиком. Не само да, када гостују у некој емисији, на захтев водитеља не знају да изрецитују ниједну једину песму, већ неки од њих толико упадљиво користе поштапалице, да постају права атракција на друштвеним мрежама. Један млади глумац је током гостовања у једној емисији изговорио више од двеста тридесет пута пошталицу овај. Нешто касније, гостујући на другом каналу на рачун овог рекорда добио је аплауз (што у очима младих 
може изгледати као афирмација управо таквих говорних навика). Управо због тога желимо да истакнемо колико је важан утицај професора и наставника у постављању стандарда правилног и доброг изражавања. Како Светлана Цветковић у свом раду наводи, свој говор посебно треба да унапређују наставници у млађим разредима основне школе, као што уопште наставници и професори треба да усавршавају свој говор имајући увек на уму да су они узори ученицима и да лепотом и богатством свог језичког израза утичу на њихов говор (Цветановић 2009: 132).

Де Сосир је сматрао да у говору проналазимо човека. У говору. Примећујемо да је његова мисао у својој суштини иста као већ поменута Сократова („Проговори да видим ко си.”). Говор је, дакле, по њиховом мишљењу, огледало човековог бића, и као такав прави је показатељ образовања и васпитања особе са којом комуницирамо. Некада, међутим, неспретност изражавања може утицати на то да се стекне погрешан утисак о некој особи. Зато је веома важан непрестан рад на квалитету усменог изражавања. Сматрамо да једино стављањем акцента на функионално знање ученика можемо истински утицати на њихову будућност, што и јесте циљ практичних примера и вежби које нудимо наставницима и професорима за рад на редовним часовима, као и на додатној настави у виду секције и ненаставних активности (при чему остављамо могућност да се одабир вежби и начин рада прилагоде тренутним околностима и интересовањима наставника/ професора и ученика).

\section{ЛИТЕРАТУРА}

Андерсон 2016: К. Андерсон, ТЕД говори, Београд: Вулкан.

Јелић 2001: В. Јелић, Античка и српска реторика, Београд: Чигоја штампа.

Марковић 2002: М. Марковић, Глас глумияа, Београд: Клио.

Николић 1992: М. Николић, Методика наставе српског језика и књижевности, Београд: Завод за уџбенике и наставна средства.

Нушић 1938: Б. Нушић, Реторика, Београд: Издавачко друштво Геца Кон.

Петровић 2014: Т. Петровић, Умеће говорењ, Нови Сад: Прометеј.

Ристовић 2013: Н. Ристовић, Приручник из реторике, Београд: Завод за уџбенике.

Роксандић 2020: С. Роксандић, Проговори да видим ко си, Нови Сад: Изражајност.

Цветановић 2009: 3. Цветановић, Говорни узори ученицима даровитим за вештину говорења, Београд: Учитељски факултет. 
Lidija Z. Savić

\title{
A METHODICAL APPROACH TO ORATORY AND THE CULLTURE OF SPEECH: ABOUTTHEIMPORTANCEOF A WELL-SPOKEN WORD
}

\begin{abstract}
Summary
The modern way of life has had a bad effect on oral expression, but it has paradoxically caused a revival of exhibition literacy and its importance and the culture of public speech in general. Although there seems to be an awareness of the importance of oral expression quality nowadays, it is important to note that it has been present since ancient times. The way we speak has always been a reflection of education and upbringing, it is one of the basic tools for presentation and self-presentation. The aim of the paper is not to put form (the way something is said) in front of the content of what is said, but to point out their interdependence, because good content without form loses its meaning, and form without content does not exist. Except for pointing out problems, the paper offers concrete solutions, applicable in everyday teaching practice.
\end{abstract}

Key words: culture of public speech, exhibition literacy, rhetoric, diction, articulation. 